\title{
動摇病発症過程に抒ける血中および尿中ホルモン動態
}

$$
\begin{aligned}
& \text { 小林 毅1) - 石井 正則 }{ }^{2)} \cdot \text { 金田 健作 }{ }^{1)} \\
& \text { 八代 利伸 }{ }^{1)} \text { - 森山 寛 }{ }^{1)} \cdot \text { 須藤 正道 }{ }^{3)} \\
& \text { 関口 千春4) }{ }^{4} \text { 五十嵐 眞 }{ }^{5)}
\end{aligned}
$$

\section{Blood and Urinary Hormone Changes in Motion Sickness}

Takeshi Kobayashi $^{1)}$, Masanori Ishii ${ }^{2)}$, Kensaku Kaneda ${ }^{1)}$ Toshinobu Yashiro' ${ }^{1)}$, Hiroshi Moriyama ${ }^{1)}$, Masamichi Sudoh ${ }^{3)}$ Chiharu Sekiguchi ${ }^{4)}$, Makoto Igarashi ${ }^{5)}$

1) Department of Otorhinolaryngology, Jikei University School of medicine

2) Department of Otorhinolaryngology, Tokyo Kosei-Nenkin Hospital

3) Laboratory of Space Medicine, Jikei University School of medicine

4) National Aerospace Development Agency of Japan

5) Universal Research Center, Nihon University

In an effort to determine the mechanism causing motion sickness, various studies have been conducted on the autonomic and central nervous systems. Recently, it was reported that the level of antidiuretic hormone $(\mathrm{ADH})$ rises when motion sickness appears, and the possible involvement of hormones in the manifestation of motion sickness has become a focus of attention.

We induced motion sickness by Colioris stimulation in healthy adult volunteers, and examined hypothalamus-pituitary-adrenal hormones and neuropeptides before and after stimulation and during the recovery process.

In the high susceptibility group blood levels of ADH, ACTH, prolactin, cortisol, $\beta$ endorphin and MET-enkephalin and urinary levels of $\mathrm{ADH}$ immediately after stimulation were significantly higher than those in the low susceptibility group. These levels returned to normal after 30 minutes of rest. In the high susceptibility group the motion sickness score immediately after stimulation showed a significant correlations with the blood levels of $\mathrm{ADH}, \mathrm{ACTH}$ and $\beta$-endorphin.

These results indicate that $\mathrm{ADH}, \mathrm{ACTH}, \beta$-endorphin and MET-enkephalin are involved in the nausea and vomiting of motion sickness. Moreover, it seems that the mechanism and effects of these hormones may differ from each other. Since the urinary level of $\mathrm{ADH}$ is very closely correlated with its blood level, the use of urinary $\mathrm{ADH}$ testing is advocated as a simple method with no discomfort.

Key words: motion sickness, hormones, $\mathrm{ADH}, \beta$-endorphin, MET-enkephalin

\footnotetext{
1) 東京慈恵医科大学耳鼻咽喉科学教室 3) 東京慈恵医科大学宇宙医学研究室 5) 日本大学総合科学研究所

2) 東京厚生年金病院耳鼻咽喉科 $\quad$ 4) 宇宙開発事業団
} 


\section{はじめに}

動摇病の発症機序として, 前庭刺激, 視覚, 深 部知覚などの平衡を維持する感覚入力情報が混乱 をきたすことにより，悪心，嘔吐，冷汗，顔面蒼 白などの自律神経症状が発現するといら説（感覚 混乱説）が現在広く支持されている。また，同時 に自律神経系の不安定な活動や空間識の混乱をさ たすといら報告1)もある。これらの動摇病の発症 する経路は, 従来前庭一自律神経反射を中心とし て関与する自律神経系拈よび中枢神経系まで様々 な検討がなされてきたが，未だ全ては解明されて いない。しかし, 動摇病の際に抗利尿ホルモン $(\mathrm{ADH})$ が上昇する事が報告2) され，動摇病に拉 ける嘔吐などの自律神経症状やその順応の過程に おいてホルモンが介在した液性調整の関与の可能 性が指摘されてきている。

今回, 我々は動摇病の発症過程とその回復期に おける視床下部一下垂体系ホルモンおよび neuro-peptide の動態とその作用の解明を目的と して健康成人を対象とした実験的研究を抏こなっ た。

\section{方法}

実験は宇宙開発事業団筑波宇宙センター内に設
置されている特殊回転椅子を使用した。回転椅子 には，頭部が正確な位置で屈曲されるように頭部 位置固定装置が装着されている。

対象は健康男性成人ボランティア11名（年齢19 歳から22歳）であり，現症および既往歴に耳疾患 を持たないものである。

測定手順は，まず被験者に問診，血圧測定等を 行った後に30分間安静とした。負荷開始直前に採 血扣よび採尿を行い，コリオリ刺激負荷による動 摇病誘発を開始した。

コリオリ刺激負荷の条件は, 被験者をゴーグル 装着による暗所開眼で回転椅子に固定し, 初速を

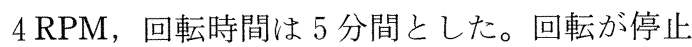
したのちに30秒間の症状聴取をおこない，動摇病 スコア (Graybiel 動摇病評価法飞準拠 3 , 図 1 ) を算定した。その後に, 回転速度をさらに 2 RPM 増速し, 5 分間の負荷を行った。以後, 同 様にして 5 分間の負荷が終了する毎に回転数を増 加し, 総負荷時間30分間まで反復負荷を行った。 椅子の回転中, 被験者はテープの指示に従い, 頭 部を前後左右に 4 秒間に 1 回, 無作為に屈曲させ, 被験者の前庭系にコリオリ刺激負荷が加わるよう にした。

\section{DIAGNOSTIC CATEGORIZATION OF DIFFERENT LEVELS OF SEVERITY OF ACUTE MOTION SICKNESS (Graybiel, 1968)}

\begin{tabular}{|c|c|c|c|c|c|}
\hline Category & $\begin{array}{l}\text { Pathognomonic } \\
16 \text { points }\end{array}$ & $\begin{array}{c}\text { Major } \\
6 \text { points }\end{array}$ & $\begin{array}{l}\text { Minor } \\
4 \text { points }\end{array}$ & $\begin{array}{l}\text { Minimal } \\
2 \text { points }\end{array}$ & $\begin{array}{l}\text { AQS * } \\
1 \text { points }\end{array}$ \\
\hline Nausea syndrome & Vomiting or retching & Nausea $†$ II. III & Nausea I & I Epigastric discomfort & Epigastric awareness \\
\hline skin color & & Pallor III & Pallor II & Pallor I & Flushing \\
\hline Cold sweating & & III & II & I & \\
\hline Increased salivation & & III & II & I & \\
\hline Drowsiness & & III & II & I & \\
\hline Pain & & & & & Headache \\
\hline $\begin{array}{l}\text { Central nervous } \\
\text { system }\end{array}$ & & & & & $\begin{array}{l}\text { Dizziness : } \\
\text { Eyes closed } \geqq \text { II } \\
\text { Eyes open III }\end{array}$ \\
\hline \multicolumn{6}{|c|}{ Leveis of Severity Identified by Total Points Scored } \\
\hline $\begin{array}{l}\text { Frank Sickness } \\
\text { ( } \mathrm{S} \text { ) } \\
\geqq 16 \text { points }\end{array}$ & $\begin{array}{l}\text { Severe Malaise } \\
(\mathrm{M} \text { III ) } \\
8-15 \text { points }\end{array}$ & $\begin{array}{c}\text { Moderate Malaise } \\
\text { ( } M \text { II A) } \\
5-7 \text { points }\end{array}$ & A & $\begin{array}{c}\text { Moderate Malaise B } \\
\text { ( M II B) } \\
3-4 \text { points }\end{array}$ & $\begin{array}{l}\text { Slight Malaise } \\
\text { ( M I) } \\
1-2 \text { points }\end{array}$ \\
\hline
\end{tabular}

$* \mathrm{AQS}=$ Additional qualifying symptoms $+\mathrm{III}=$ severe or marked $\mathrm{II}=$ moderate $\mathrm{I}=$ slight

図 1 動摇病スコア算定基準

(Graybiel の Diagnostic score に準拠) 
負荷の中止条件としては

1）被験者から中止の訴えがあった場合

2) 動摇病スコアにて 8 点以上になった場合

3 ）嘔吐を和こした場合

4 ) 実験担当医師が中止すべきと判断した場合 のいずれかとした。

これらの中止条件を満たすか，総負荷時間が 30 分となった被験者は負荷を終了とし，その直後の 血圧測定, 採血, 採尿扣よび動摇病スコア算定を 扎こなった。この後, 30分間被験者を安静とした のちに, 血圧測定, 採血叔よびスコア算定を和こ なって実験を終了した（図 2)。

測定した血中拈よび尿中ホルモンは以下の項目 を選択し，同時に血清浸透圧和よび尿浸透圧を測 定した。

血中：副腎皮質刺激ホルモン $(\mathrm{ACTH})$
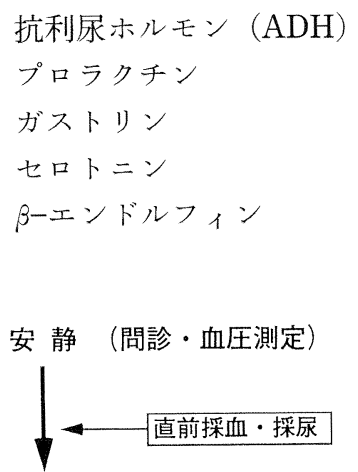

コリオリ加速度負荷

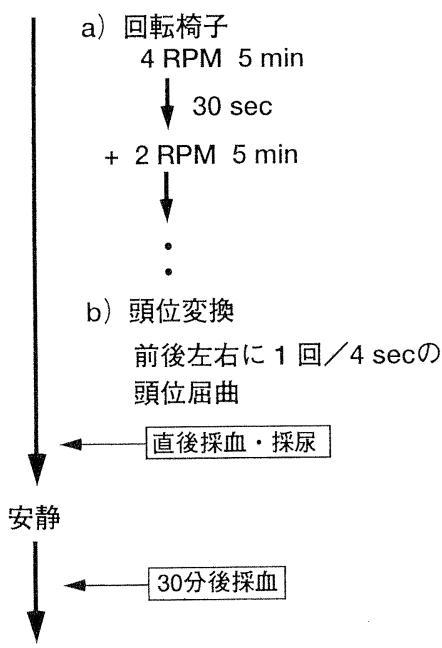

図 2 測定手順

動摇病スコアは30秒間の負荷休止時間毎执よび負荷 終了直後に，症状を視診拈よび問診し算定する。

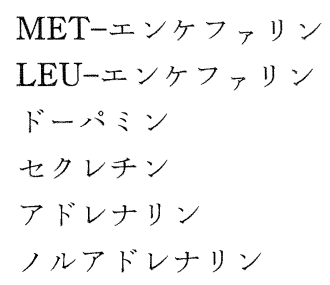

尿中：抗利尿ホルモン $(\mathrm{ADH})$

$17-\mathrm{KS}$

17-OHCS

11-DEO-17K

$11-\mathrm{OXY}-17 \mathrm{~K}$

動摇病スコアによって数值化された被験者の症 状の程度に従って, 各被験者を動摇病の易罹患性 (susceptibility) が高度から中等度の群（High susceptibility 以後 HS 群) と低度の群（Low susceptibility 以後 LS 群）とに分類した。各群の 基準は以下の如くとした。

HS 群：負荷終了時のスユアが 8 点以上もしく は負荷時間30分未満

LS 群：負荷終了時のスコアが 8 点未満かつ負 荷時間30分

今回 HS 群は 8 名, LS 群は 3 名であった。

\section{結 果}

a)負荷前後におけるホルモン值の変動

血中 ACTH 濃度は HS 群で負荷後有意に上昇 し, 負荷後30分で急速に低下したが, LS 群では 有意な変化を認めなかった。また，血中コルチゾー ル濃度は HS 群 LS 群ともに負荷直後に有意な上 昇を示したが，HS 群では負荷後30分でも高い濃 度を維持した（図 3 ）。

血中カテュールアミン濃度は，アドレナリンは HS 群に执いて負荷直後に有意な上昇を示し，負 荷後30分に扣いても高值を認めたが，LS 群では 負荷直後に軽度の高值を示したものの負荷後30分 では負荷前のレベルに戻った。一方，ノルアドレ ナリンはHS, LS 群ともに大きな変化を認めず, 特に HS 群では低下傾向を示した（図 4)。

血中プロラクチン濃度は HS 群で負荷直後に ピークを持つ有意な上昇を認めたが，LS 群では 変化を認めなかった（図 5 )。

Opioid-peptide である $\beta$-ェンドルフィンと METーエンケファリンの血中濃度はいずれも HS 群に扣いて負荷後有意に上昇し, LS 群は大きな 変化を認めなかった（図 6 ）。一方，LEU-エン 

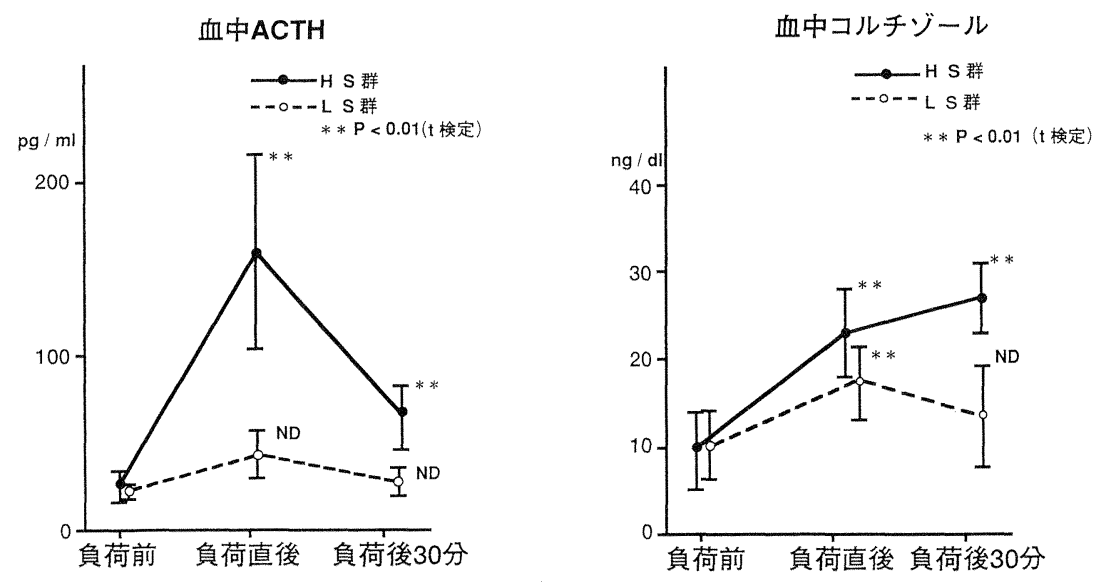

図 $3 \mathrm{ACTH}$ 拉よびュルチゾール血中濃度变化

HS 群 : High Susceptibility 群

LS 群 : Low Susceptibility 群
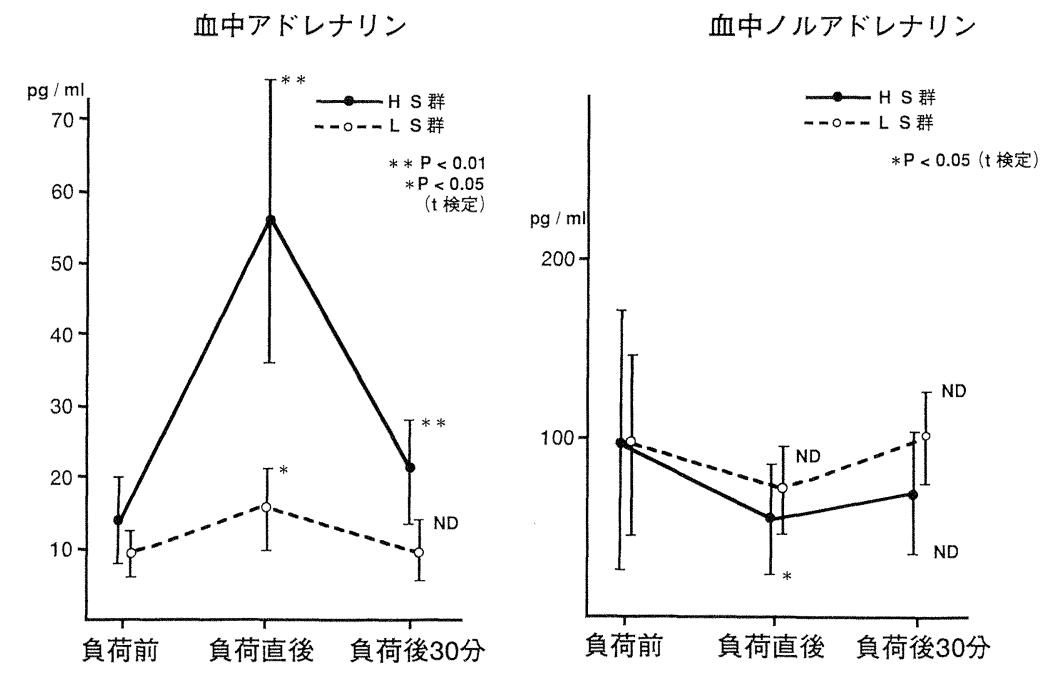

図4 カテュールアミンの血中濃度変化

ケファリンは HS, LS 群ともに变化を認めなかっ た。

血中 $\mathrm{ADH}$ 濃度は，負荷直後に HS 群に扮いて LS 群の約 20 倍という著しい高值を示し, 尿中 $\mathrm{ADH}$ もHS 群で LS 群の約16倍の高值を示した が，LS 群ではいずれも汪とんど变化を示さなか った。また, 血中 $\mathrm{ADH}$ 濃度は, 負荷終了後30分 ですみやかに正常範囲内に低下した（図 7 ）。 $\mathrm{ADH}$ の分泌㳘響を与える血清浸透圧特よび尿 浸透圧は HS 群と LS 群の両者で全く変化を認め
なかった。

その他の測定項目であるセロトニン，ガストリ ンとドーパミンの各血中濃度と尿中ステロイド代 謝産物である 17-KS，17-OHCS，11-DEO-17K 拉 よび 11-OXY-17K の各尿中濃度は HS, LS 群と もに有意な変化を認めなかった。

b) 血中ホルモン濃度と susceptibility の相関 コリオリ負荷直後の各被験者に打将る動摇病ス コア值と血中 ACTH, ADH および $\beta$-エンドルフ ィン濃度の相関係数を検討した。その結果, 


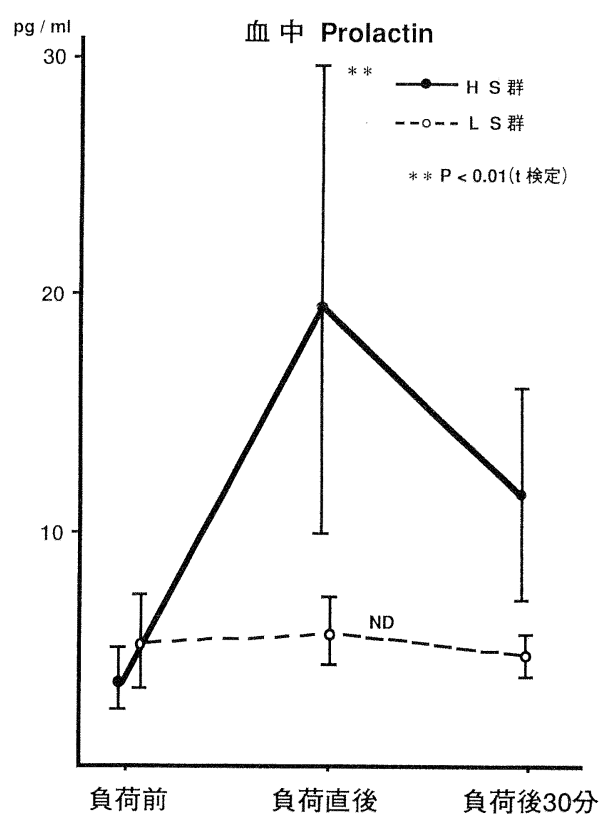

図 5 プロラクチン血中濃度変化

血中 $\beta$ - エンドルフィン

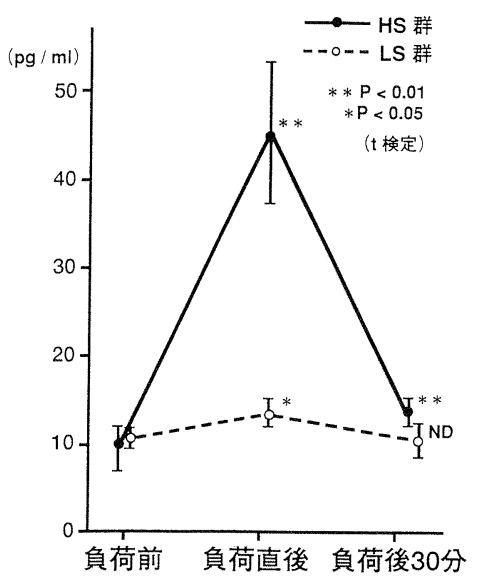

血中 MET - エンケファリン

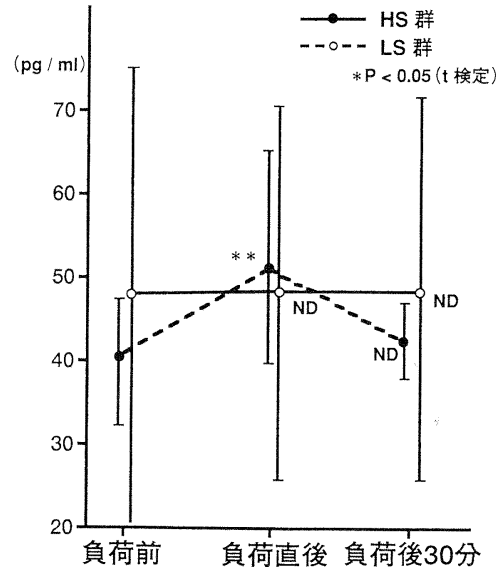

図 6 opioid-peptide 9 血中濃度変化

$\mathrm{ADH}$ は相関係数 $\mathrm{r}=0.69(\mathrm{p}<0.01)$ とやや高い 相関を認め, $\beta$-エンドルフィンは $\mathrm{r}=0.67(\mathrm{p}<0$. 01), ACTH $\mathrm{r}=0.65(\mathrm{p}<0.05)$ の相関を認め た（図 8，9）。

一方, 負荷前に技任る安静時の血中 ACTH, $\mathrm{ADH}$ 特よび $\beta$-エンドルフィン濃度と負荷直後の 動摇病スコア值は有意な相関を認めなかった。
考察

動摇病の発症機序として，末梢前庭情報抢よび 視覚情報が混乱をさたすことにより, 悪心, 嘔吐, 冷汗, 顔面蒼白などの自律神経症状が発現すると いう感覚混乱説は現在広く支持されている。一方, 感覚情報の混乱が自律神経症状として発症する経 路は, 従来前庭一自律神経反射を代表とする反射 
血中 $A D H$

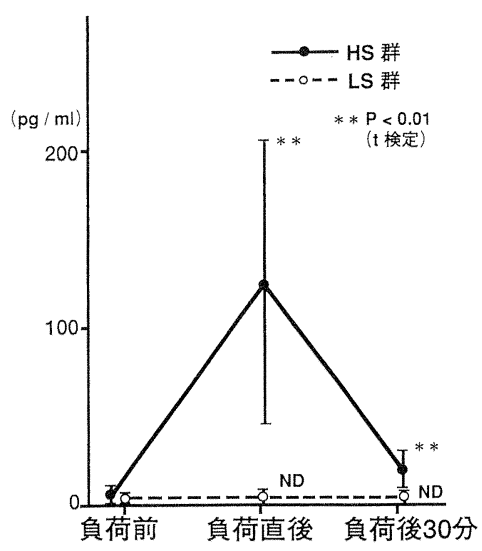

尿中 $\mathrm{ADH}$

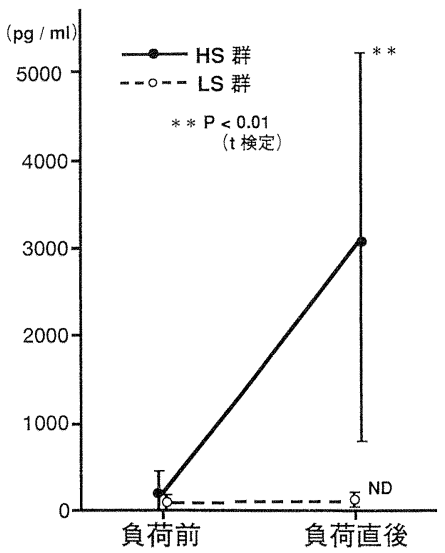

図 $7 \mathrm{ADH}$ の血中特よび尿中濃度変化
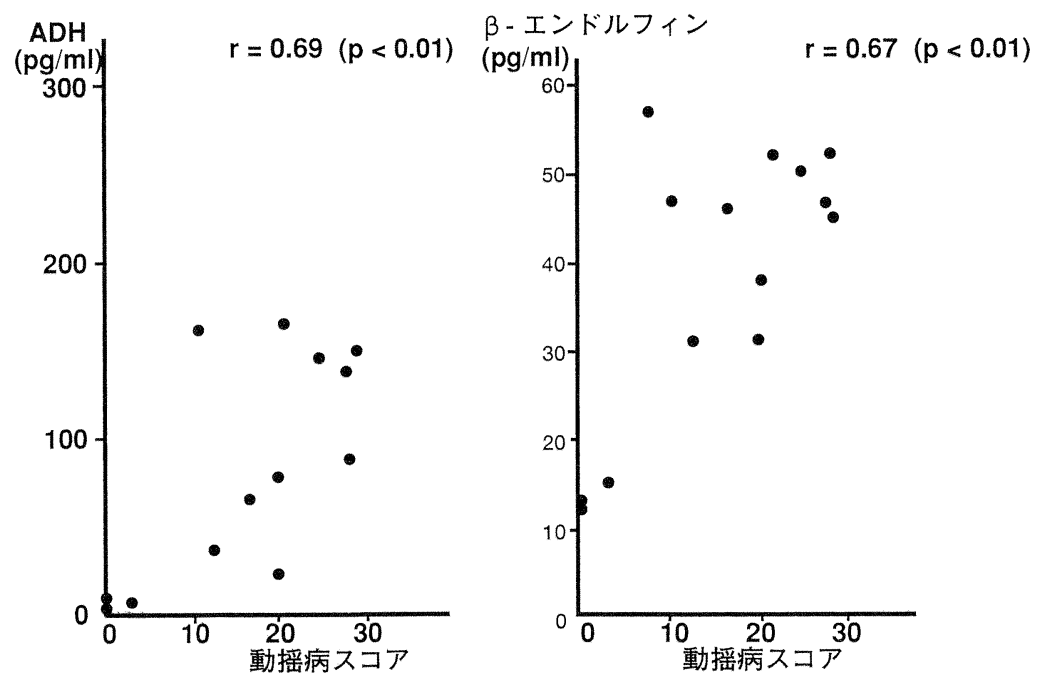

図 8 負荷直後の $\mathrm{ADH}$ 拈よび $\beta$-エンドルフィン血中濃度と動摇病スコアの相関

弓の存在の検討を始めとして，末梢から中枢神経 系の様々なニューロンの検索が行われてきた。こ れら各種の反射弓や促進的拈よび抑制的ニューロ ンの発見により動摇病の発症機序にかなりの解明 がもたらされてはきたが，動摇病の易罹患性 (susceptability) の個人差, 訓練による慣れ括よ び精神的な影響などに充分な説明を与えるには困 難な面をいまだ残している。

近年, 各種ホルモンの定量検査の進歩とともに, 手術侵襲や運動負荷によってステロイドをはじめ とする視床下部一脳下垂体一副腎系ホルモンの血
中濃度が上昇することが指摘され，これらのホル モン上昇と生体に掠けるストレスへの適応との関 連が注目されてきている。さらに，Eversmann らが動摇病の際に $\mathrm{ADH}$ の血中濃度が上昇する事 を報告2) し，動摇病に扮いて ADHを含も視床下 部一脳下垂体一副腎系ホルモンが何らかの役割を 演じている可能性が示唆された。当教室の八代4) は，今回我々が扔こなった実験と同じプロトコー ルで健康成人 15 名に対して動摇病誘発を行い, 動 摇病スコアに拈けるHS 群に括いて $\mathrm{ADH}$, $\mathrm{ACTH}, \mathrm{PRL}$ の血中濃度が動摇病誘発直後に高 


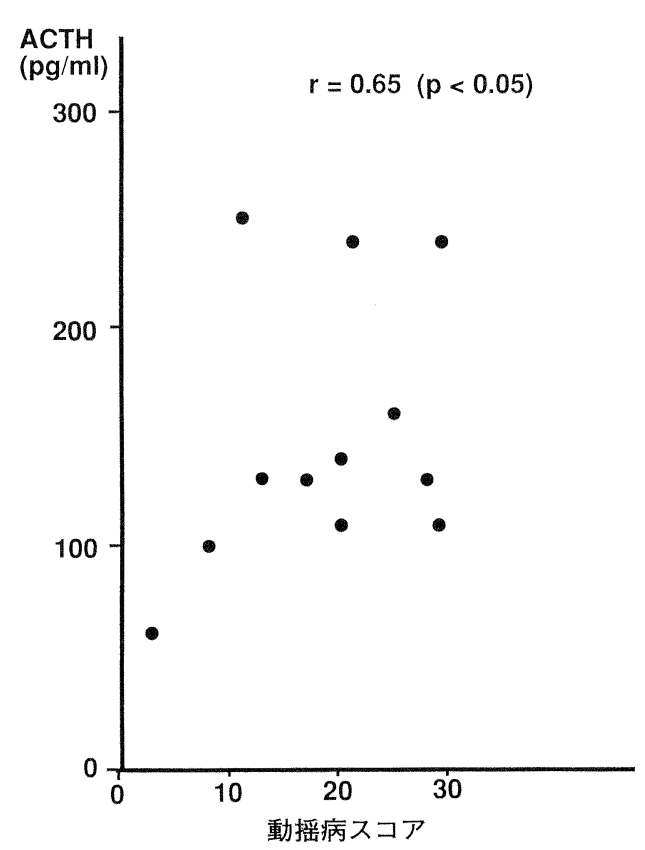

図 9 負荷直後の ACTH 血中濃度と動摇病スコア の相関

值を示すことを指摘し, 動摇病の発症に括ける $\mathrm{ADH}$ の関与を示唆した。

今回我々は，これらの報告をらま光， $\mathrm{ADH，}$ ACTH に加光て Opioid-peptide である $\beta$-エンド ルフィン, MET-エンケファリン, LEU-エンケ ファリンの血中濃度測定を扣こなった。その結果, 動摇病誘発直後に血中の ADH, ACTH は著しい 上昇を示し, 30分の安静によって急速に低下した。 $\mathrm{ADH}$ が嘔気や嘔吐と強い関連を持つことが近年 指摘され，それ関連する報告も多い。従来は， $\mathrm{ADH}$ は嘔気や嘔吐による反応として二次的に血 中濃度が上昇すると考劣られていたが，ラットの chemoreceptor triger zone (CTZ) に ADH のレ セプターが存在し, $\mathrm{ADH}$ が嘔吐の発現に直接的 に関与している可能性があるとする報告5)や，さ らに動摇病やめまい疾患の発症自体に関与してい る可能性を示す報告6) る久られる。動摇病の susceptibility 飞関しても, 安静時の血中 ADH, ACTH 濃度が動摇病の susceptibility と相関する という報告2）7）がある。今回の結果では, 安静時 の血中 ADH 拈よび ACTH 濃度は動摇病誘発時 の動摇病スコアとの相関は認められず, 誘発直後 の血中 $\mathrm{ADH}, \mathrm{ACTH}$ 拉よび $\beta$-エンドルフィン濃
度と動摇病誘発直後の動摇病スコアは有意な相関 を認めた。この結果からは $\mathrm{ADH}, \mathrm{ACTH}$ 抢よび ß-エンドルフィンが動摇病の症状である嘔気, 嘔吐により二次的に血中濃度が上昇するのか, あ るいはとの発症自体に関与するのかは結論つけ忷 れなかった。しかし, 動摇病の自律神経症状と $\mathrm{ADH}$ 和よび ACTH の強い相関関係は示唆され た。また, ACTH に刺激され, 血中コルチゾー ルは負荷直後より上昇するが, ACTH の半減期 は $\mathrm{ADH}$ よりやや長く, 負荷終了後30分に扣いて も高值を維持した。ACTH はコルチゾールを介 して動摇病に関与しているとすれば, ACTH と $\mathrm{ADH}$ はその主に機能する時点や作用が異なるこ とが考えられる。

また, $\mathrm{ADH}$ はその半減期が約 8 分と短く, ほ 涪尿中に排泄されるため尿中 $\mathrm{ADH}$ 濃度は血中 $\mathrm{ADH}$ 濃度と強い相関を示し, 動摇病やめをい患 者の血中 $\mathrm{ADH}$ 濃度定量検査に対する非侵襲的か つ簡便な簡易検査として有用と思われた。

Opioid-peptide のらちßーエンドルフィンおよ び METーエンケファリンは負荷直後にピークを 持つ著しい上昇を認め, 負荷直後の血中 $\beta$-エン ドルフィン濃度と負荷直後の動摇病スコアに执い ても 1\%の危険率で有意な相関関係を認めた。脳 内にはモルヒネと結合する受容体があり，これら の麻薬受容体と結合するペンタペプチドがエンケ ファリンであり MET-エンケファリンと LEUエンケファリンがある。これらより大きな 2 種類 のペプチドが $\alpha$-エンドルフィンと $\beta$-エンドルフ ィンであり，これらはいずれも脳内麻薬様物質と して, 出産, 手術, 運動などの負荷によって血中 濃度が上昇することが知られている。市た, 嘔吐 中枢である CTZ やVomiting center ヒェンケフ フリンのレセプターが存在するといら報告8) や, blocker としてナロキソンを投与すると動摇病が 増強するといら報告9）もあり，悪心や嘔吐に対す るこれらのホルモンの直接的な作用も考光られ る。一方で, 運動に捺忊る $\beta$-エンドルフィンの 血中濃度は, 運動負荷の初期に上昇し, その運動 プログラムに順応すると低下寸るが，運動負荷前 の血中濃度よりは高いレベルに維持される10)。こ のことは, $\beta$-エンドルフィンが順応のプロセス に関与しているものと考党られる。これらのこと から， $\beta$-エンドルフィンと MET-エンケファリ 
ンの動摇病誘発に括壮る血中濃度の上昇は動摇病 に対寸る生体の順応関与している可能性がある と思われる。

また, 最近化学療法に伴ら悪心, 嘔吐に対して 末梢性セロトニン拮抗薬である 5-HT3 blocker が 臨床的に広く使用されているが, 動摇病には無効 とする報告8）もある。今回の実験でセロトニンの 血中濃度は HS, LS 群のいずれも変化しなかった 事は，末梢性にセロトニンを拮抗しても動摇病発 症に影響を与えないといらことの傍証になると考 えられる。

本実験の結果から, 動摇病に和ける悪心, 嘔吐 などの自律神経症状の発現と代償のいずれかの過 程に颃いて, 視床下部一下垂体一副腎系ホルモン, 特に急性のストレス反応で上昇するといわれる $\mathrm{ADH}, \mathrm{ACTH}$ 扣よび Opioid-peptide が深く関与 している可能性が高いことが示された。これらの 変化の主な中枢は，一般に上位中枢であるとされ る大脳辺縁系が想起され, 各知覚系情報の混乱や 空間識の混乱 $\left.{ }^{1}\right)$ が大脳辺縁系を刺激し, 視床下部 一下垂体系ホルモンの著しい分泌充進を引き起こ した可能性が考えられる。しかし，その関与する 動摇病発症の段階や，その作用機序に関して明確 な回答を得ることは本実験の結果からだけでは困 難である。今後，これらのホルモンの作用とその 機序をより深く検討することは動摇病発症経路の 解明や向精神薬と異なる抗動摇病薬の開発の一助 となることが期待される。

\section{まとめ}

1) 動摇病に打将る視床下部一下垂体一副腎系 ホルモンの血中拈よび尿中動態を解明する目的 で，健康成人男性に対しコリオリ加速度負荷によ る動摇病誘発を行い, その負荷前後および負荷後 30分の血中拉よび尿中の視床下部一下垂体一副腎 系ホルモン， $\beta$ ーンドルフィンおよびェンケフ ァリン濃度を測定した。

2) HS 群に执いて負荷直後に血中の $\mathrm{ADH}$, $\mathrm{ACTH}, \mathrm{PRL}$, コルチゾール, $\beta$-エンドルフィン, METーエンケファリン执よび尿中の $\mathrm{ADH}$ の有意 な上昇を認めたが, 血中ガストリン，セロトニン， ドーパミン，セクレチン，LEU-エンケファリン 拉よび尿中ステロイド代謝産物濃度に変化を認め なかった。

3) HS 群の負荷直後の動摇病スコアと $\mathrm{ADH}$,
$\mathrm{ACTH}$ 特よび $\beta$ ーエンドルフィンの血中濃度には 有意な相関関係を認めた。

4 ) これらの結果から, 動摇病に抢汀悪心, 嘔吐の発現に $\mathrm{ADH}, \mathrm{ACTH}, \beta$-エンドルフィン 拈よび METーエンケファリンが関与しているこ とが示唆され，またその機序や作用は各々異なる 可能性があることが推測された。

5 ) 尿中の $\mathrm{ADH}$ 濃度は血中濃度とよく相関し, 非侵襲的かつ簡便な検査として有用と思われた。

本論文の要旨は第51回日本平衡神経科学会総会 に执いて発表した。

\section{文献}

1) 石井正則, 八代利伸, 小林 毅, 他 : 航空機 搭乗員の空酔い対策一具体的プログラムとそ の結果について一。耳展 37: 95-100, 1994

2 ) Eversmann T, Gottsmann M, et al: Increased secretion of growth hormone, prolactin, antidiuretic hormone, and cortisol induced by the stress of motion sickness. Aviat Space Environ Med 49: 53-57, 1978

3 ) Graybiel A, Wood CD, Miller EF, et al: Diagnostic criteria for grading the severity of acute motion sickness. Aerospace Med 39: 453-455, 1968

4 ）八代利伸：コリオリ加速度負荷による動摇病 誘発時の血中ホルモンの変動について.耳展 34 補 $5:$ 383-396, 1991

5 ) I. Merchenthaler, S Vigh, P Petrusz, et al: Immunocytochemical localization of corticotropin-releasing factor (CRF) in the rat brain. Am J Ana 165: 385-396, 1982

6 ) 石井正則, 八代利伸, 白沢昭弘, 他 : メニエー ル病と ADH そついて. Equilibrium Res 50: 62, 1991

7 ) R1 Kohl: Endocrine correlates of susceptibility to motion sickness. Aviat Space Environ Med: 1158-1165, 1985

8 ) Rl Kohl, S MacDonald: New pharmacological approaches to the prevention of Space/ motion sickness. J Clin Pharmacol 31: 934946, 1991

9) ME Allen, C MaKay, DM Eaves, et al: Naloxone enhances motion sickness: Endorphins 
implicated. Aviat Space Environ Med: 647653, 1986

10) JC Prior: Endocrine "conditioning" with endurance training: a preliminary review. Can J Appl Sport Sci 7: 148-157, 1982
原稿到着：平成 6 年 8 月 12 日

別刷請求先 : 小林 毅

テ105 東京都港区新橋3-25-8

東京慈恵会医科大学耳鼻咽喉科学教室) 